\title{
FAKTOR KEPATUHAN PEKERJA PADA KAWASAN TANPA ROKOK (KTR) DI PT. PAL INDONESIA (PERSERO)
}

\author{
WORKER OBEDIENCE FACTORS OF NON SMOKING AREA IN PT. PAL \\ INDONESIA (PERSERO)
}

\section{Rizka Fitria Fajrin}

PT. Jameson Freight Semesta, Perak Utara, Surabaya

E-mail: rizka675@gmail.com

\begin{abstract}
Background: The workplace is every room where the workers work with various sources of danger. Hazards that can occur include fire, work accidents and occupational diseases. Fire may occur due to electrical short circuit, human negligence and ignition of flammable liquids and gases. Workers who throw cigarettes carelessly become a trigger of fire and even blasting at work. Therefore, the government made a policy on restrictions on the use of cigarettes in the workplace, the Non Smoking Area. Although regulations relating to non smoking areas have been established and legalized, there are still non smoking area violations. PT. PAL Indonesia (Persero) has had regulations related to non smoking areas that have been applied in the company. But in some places still found a cigarette butts are scattered. This indicates that there are still workers who smoke indiscriminately and do not throw cigarette butts to the proper place. Purpose: The purpose of this study is to analyze factors relates to non smoking area adherence at PT. PAL Indonesia (Persero) in terms of Milgram's Obedience theory. Methods: The method in this research is analytic observasional with quantitative approach and cross sectional research design. Results: The results of this study indicate that factors related to obedience of non smoking area are personal responsibility with a significant value of $0.031(p<0.05)$. Conclusion: Workers at PT. PAL Indonesia (Persero) has good obedience of non smoking area in terms of personal responsibility.
\end{abstract}

Keywords: obedience, cigarette, non smoking area, work place

\section{ABSTRAK}

Latar Belakang: Tempat kerja merupakan tiap ruangan untuk bekerja dimana terdapat berbagai sumber bahaya di dalamnya. Bahaya yang dapat terjadi antara lain kebakaran, kecelakaan kerja, dan penyakit akibat kerja. Kebakaran dapat terjadi akibat korsleting listrik, kelalaian manusia serta tersulutnya cairan dan gas yang mudah terbakar. Puntung rokok yang dibuang secara sembarangan oleh pekerja di tempat kerja dapat menjadi pemicu kebakaran bahkan ledakan di tempat kerja. Hal ini menjadi alasan pemerintah dalam membuat kebijakan tentang larangan penggunaan rokok di tempat kerja, yakni Kawasan Tanpa Rokok (KTR). Peraturan terkait KTR telah dibuat dan disahkan, namun masih ditemukan adanya pelanggaran KTR. PT. PAL Indonesia (Persero) sendiri telah memiliki peraturan terkait KTR yang telah diterapkan di perusahaan. Namun di beberapa tempat masih ditemukan adanya puntung rokok yang berserakan. Hal ini menandakan bahwa masih terdapat pekerja yang merokok sembarangan dan tidak membuang puntung rokok ke tempat yang semestinya. Tujuan: tujuan penelitian ini yakni untuk menganalisis hubungan antara faktor-faktor pada Teori Milgram dengan kepatuhan Kawasan Tanpa Rokok (KTR) di PT. PAL Indonesia (Persero). Metode: Metode dalam penelitian ini adalah analitik observasional dengan pendekatan kuantitatif dan desain penelitian cross sectional. Hasil penelitian ini menunjukkan bahwa faktor yang berhubungan dengan kepatuhan KTR adalah tanggung jawab personal dengan nilai 
signifikan 0,031 ( $\mathrm{p}<0,05)$. Kesimpulan: Pekerja di PT. PAL Indonesia (Persero) telah memiliki kepatuhan Kawasan Tanpa Rokok yang baik dilihat dari faktor tanggung jawab personal.

Kata Kunci: kepatuhan, rokok, Kawasan Tanpa Rokok, tempat kerja

\section{PENDAHULUAN}

Undang-undang No. 1 Tahun 1970 menyebutkan bahwa tempat kerja merupakan tiap ruangan atau lapangan tertutup atau terbuka, bergerak atau tetap dimana tenaga kerja bekerja, atau yang sering dimasuki tenaga kerja untuk keperluan suatu usaha dan terdapat berbagai sumber bahaya. Bahaya yang dapat terjadi antara lain kebakaran, kecelakaan kerja, dan penyakit akibat kerja. Penyediaan perlindungan keselamatan dan kesehatan tenaga kerja merupakan hal utama yang wajib diadakan di suatu perusahaan. Perusahaan perlu upaya untuk menjaga dan melindungi status kesehatan tenaga kerja yang ada di dalamnya. Upaya tersebut dapat dilihat dari adanya program yang menunjang keselamatan dan kesehatan kerja yang dibutuhkan oleh tenaga kerja. Upaya yang dapat dilakukan dalam area promotif dan preventif di tempat kerja yaitu penerapan program promosi kesehatan yang ada di perusahaan. Penerapan program dapat dimulai dengan dibuatnya suatu kebijakan oleh manajer, sehingga program yang akan dilaksanakan dapat sesuai dengan kondisi yang ada di lapangan. Penanganan juga harus sesuai dengan potensi bahaya yang akan ditimbulkan.

Kebakaran merupakan bahaya yang dapat menimbulkan risiko langsung pada keselamatan pekerja; merusak fasilitas, alat, dan bahan yang ada di tempat kerja. Hal ini mengakibatkan perusahaan mengalami kerugian yang cukup besar jika terjadi kebakaran. Kebakaran dapat terjadi akibat korsleting listrik, kelalaian manusia serta tersulutnya cairan dan gas yang mudah terbakar (Permana, 2015). Tempat kerja yang memiliki material seperti tumpukan sampah kertas, gas LPG serta cairan kimia, akan mudah terbakar jika ada sumber panas seperti puntung rokok yang menyala. Puntung rokok yang dibuang sembarangan oleh pekerja di tempat kerja menjadi pemicu kebakaran bahkan ledakan pada suatu tempat kerja.
Rokok juga berdampak negatif pada kesehatan pekerja seperti kanker paru-paru dan kanker saluran pernapasan. Pekerja yang terkena penyakit akibat rokok tidak dapat bekerja secara optimal, sehingga dapat menghambat produktivitas di suatu perusahaan. Hal ini mendorong perusahaan harus mencari tenaga tambahan atau tenaga pengganti untuk menstabilkan kegiatan produksi, sehingga perusahaan harus mengeluarkan biaya untuk mencari tenaga baru. Wakil Ketua Komisi IX DPR RI, Ermalena, mengatakan bahwa rokok dapat mengancam pembangunan karena dapat menurunkan produktivitas penduduk Indonesia. Penurunan tersebut dapat terlihat pada perokok yang mengaku tidak bisa berpikir jika tidak merokok (Anonim, 2017).

Menurut Anderson (1979), pengertian kebijakan publik adalah kebijakankebijakan yang dikembangkan oleh badanbadan dan pejabat-pejabat pemerintah. Tujuan kebijakan publik adalah dapat dicapainya kesejahteraan masyarakat melalui peraturan yang dibuat oleh pemerintah. Menurut Thomas R. Dye, kebijakan publik merupakan apa saja yang dipilih oleh pemerintah untuk dilakukan atau tidak dilakukan, apabila pemerintah memilih untuk melakukan sesuatu maka harus ada tujuan, selain itu kebijakan tersebut harus meliputi semua tindakan pemerintah, bukan semata-mata pernyataan keinginan pemerintah atau pejabatnya. Sesuatu yang tidak dilaksanakan oleh pemerintah juga termasuk kebijakan negara. Hal ini disebabkan "sesuatu yang tidak dilaksanakan" oleh pemerintah akan mempunyai pengaruh yang sama besarnya dengan sesuatu yang dilaksanakan oleh pemerintah. Kesimpulan dari pengertian yang telah dijabarkan yaitu kebijakan publik merupakan serangkaian tindakan atau kegiatan yang dibuat oleh badanbadan tertentu atau pejabat pemerintah untuk kesejahteraan masyarakat.

Fokus utama dari kebijakan publik dalam negara modern yaitu pelayanan 
publik. Pelayanan publik merupakan segala sesuatu yang dapat dilakukan oleh negara untuk mempertahankan atau meningkatkan kualitas kehidupan orang banyak. Hal ini menjadi alasan pemerintah untuk membuat kebijakan terkait rokok yang dirasa memiliki dampak negatif bagi kualitas hidup masyarakat. Salah satu kebijakannya adalah Undang-undang Republik Indonesia No. 36 Tahun 2009, yang menyebutkan bahwa penggunaan bahan yang mengandung zat adiktif diarahkan agar tidak mengganggu dan membahayakan kesehatan. Salah satu produk yang mengandung zat adiktif adalah tembakau, yang penggunaannya dapat menimbulkan kerugian bagi diri sendiri maupun masyarakat. Kebijakan Kawasan Tanpa Rokok (KTR), yakni Peraturan Pemerintah Republik Indonesia No. 19 Tahun 2003 yang menyebutkan bahwa tempat kerja dinyatakan sebagai Kawasan Tanpa Rokok (KTR). Kawasan Tanpa Rokok adalah ruangan atau area yang dinyatakan dilarang untuk kegiatan produksi, penjualan, iklan, promosi maupun penggunaan rokok; artinya, pemerintah telah melarang pekerja yang memiliki kebiasaan merokok. Pekerja tidak dapat merokok secara sembarangan di tempat kerja. Pimpinan atau penanggung jawab perusahaan perlu menyediakan tempat khusus untuk merokok yang letaknya jauh dari KTR serta dilengkapi dengan alat penghisap udara atau memiliki sirkulasi udara yang baik. Hal ini untuk mengembalikan hak para perokok yang pekerja.

Salah satu tahapan dari kebijakan publik adalah implementasi atau penerapan kebijakan. Dampak dan kinerja dari kebijakan tersebut akan terlihat pada tahap ini. Serta dapat diketahui apakah kebijakan yang dibuat telah mencapai tujuan yang diharapkan atau sebaliknya. Keberhasilan implementasi menurut Merilee S. Grindle (1980) dipengaruhi oleh dua variabel besar, yakni isi kebijakan dan lingkungan implementasi. Isi kebijakan dapat mencakup sejauh mana kepentingan kelompok sasaran termuat dalam isi kebijakan, jenis manfaat yang diterima oleh kelompok target, sejauh mana perubahan yang diinginkan dari sebuah kebijakan, apakah letak sebuah kebijakan telah menyebutkan subjek yang mengimplementasikan dengan rinci, serta apakah sebuah program didukung oleh sumber daya yang memadai; sedangkan variabel lingkungan kebijakan mencakup seberapa besar kekuasaan, kepentingan dan strategi yang dimiliki oleh para aktor yang terlibat dalam implementasi kebijakan, karakteristik dan rezim yang sudah berkuasa, serta tingkat kepatuhan dan responsivitas kelompok sasaran (Subarsono, 2005).

Meskipun telah banyak peraturan yang ditetapkan oleh pemerintah terkait KTR, tetapi pada penerapannya masih ditemukan berbagai pelanggaran, seperti ditemukannya beberapa pengunjung RSUD dr. Mohamad Soewandhi Surabaya yang merokok di area parkir mobil, depan pintu masuk lobi dan taman (Yusuf, 2014). Yayasan Lembaga Konsumen Indonesia (YLKI) melakukan survei tepatnya pada tahun 2010 di DKI Jakarta. Survei tersebut menemukan pelanggaran terhadap KTR. Kantor-kantor pemerintah daerah memiliki jumlah pelanggar tertinggi yaitu sebesar 45\% (Rahajeng, 2015), serta ditemukannya beberapa puntung rokok yang tersebar di area produksi di PT. PAL Indonesia (Persero), yang seharusnya area tersebut dilarang untuk merokok.

Tujuan dari penelitian ini yakni untuk menganalisis hubungan antara faktor-faktor yang terdapat dalam teori kepatuhan Milgram dengan kepatuhan KTR di PT. PAL Indonesia (Persero).

\section{METODE}

Metode yang digunakan dalam penelitian ini adalah analitik observasional dengan pendekatan kuantitatif. Penelitian ini menggunakan sampel dan populasi penelitian. Teknik yang digunakan untuk pengambilan sampel adalah simple random sampling yang dihitung menggunakan aplikasi Sample Size. Berdasarkan waktu pengambilan data, penelitian ini termasuk pendekatan cross sectional.

Peneliti menggunakan lembar kuesioner yang terdiri dari 28 pernyataan yang mencakup legitimasi figur otoritas, status lokasi, kedekatan figur otoritas, status figur otoritas, kedekatan figur otoritas, tanggung jawab personal, dukungan rekan kerja serta kepatuhan KTR. Kuesioner diberikan pada salah satu divisi yang memiliki risiko tinggi terhadap kebakaran dan merupakan divisi terbesar di PT. PAL Indonesia (Persero). 
Jumlah populasi pada divisi tersebut sejumlah 235 pekerja, karena keterbatasan peneliti terkait waktu dan lokasi penelitian maka dilakukan pengambilan sampel sejumlah 75 pekerja.

Data yang diperoleh terdiri dari data primer dan sekunder. Data primer adalah data yang didapatkan dari hasil kuesioner yang selanjutnya diolah dengan aplikasi SPSS dengan menggunakan uji Korelasi Spearman, dengan $p$ value 0,05 . Data yang telah diperoleh akan dihitung menggunakan Skala Likert. Data tersebut dikategorikan menjadi 3 kategori yakni tinggi, sedang, dan rendah. Adapun penentuan kategori sesuai dengan penghitungan yang telah dilakukan dengan skoring seperti pada Tabel 1.

Data sekunder adalah informasi terkait kebijakan terkait KTR yang diterapkan di PT. PAL Indonesia (Persero).

\section{HASIL DAN PEMBAHASAN}

PT. PAL Indonesia (Persero) merupakan sebuah perusahaan yang berdiri sejak pemerintahan Hindia Belanda pada tahun

Tabel 1. Scoring Pengkategorian Pervariabel

\begin{tabular}{lccc}
\hline \multirow{2}{*}{ Variabel } & \multicolumn{3}{c}{ Skor } \\
\cline { 2 - 4 } & Tinggi & Sedang & Rendah \\
\hline $\begin{array}{l}\text { Kedekatan } \\
\text { Pengawas }\end{array}$ & $>14$ & $10-14$ & $<10$ \\
dengan & & & \\
Pekerja & & & \\
\hline Tanggung & $>14$ & $10-14$ & $<10$ \\
Jawab & & & \\
Pekerja & & & \\
Terhadap & & & \\
$\begin{array}{l}\text { Peraturan } \\
\text { KTR }\end{array}$ & & & \\
\hline Dukungan & $>14$ & $10-14$ & $<10$ \\
Rekan Kerja & & & \\
Terhadap & & & \\
$\begin{array}{l}\text { Peraturan } \\
\text { KTR }\end{array}$ & & & \\
\hline Status & $>14$ & $10-14$ & $<10$ \\
Pengawas & & & \\
dalam & & & \\
Perusahaan & & & \\
\hline Kepatuhan & $>14,67$ & $9,33-$ & $<9,33$ \\
KTR & & 14,67 & \\
\hline
\end{tabular}

1939. Sebagai industri pembuatan kapal dan pernah menghadapi persaingan pasar internasional yang semakin kompetitif, PT. PAL Indonesia (Persero) membangun sinergi dengan perusahaan global maupun lokal dan bidang finansial, teknologi maupun logistik. PT. PAL Indonesia (Persero) telah memperoleh sertifikasi di sistem manajemen lingkungan dan pembangunan kapal yang bertaraf internasional ISO 9001, ISO 14001 dan OHSAS 180001.

Pada divisi tempat diambilnya data penelitian, memiliki beberapa tugas, diantaranya:

1. Melaksanakan perencanaan pembangunan kapal-kapal sesuai dengan kebijakan Direktur Pembangunan Kapal.

2. Melaksanakan pemasaran dan penjualan untuk produk dan jasa bagi fasilitas idle capacity.

3. Merinci IPP (Instruksi Pelaksanaan Proyek) yang telah dibuat oleh Direktur Pengembangan Kapal menjadi jadwal pelaksanaan proyek dan nilai biaya proyek yang terperinci.

4. Melaksanakan pembangunan kapal secara efektif dan efisien sesuai aspek QCD (Quality, Cost and Delivery).

5. Mengendalikan dan mengawasi pelaksanaan pembangunan proyek agar mendapatkan hasil yang memenuhi standar kualitas dengan menggunakan biaya, tenaga, material, peralatan keselamatan kerja, dan waktu yang paling efektif.

PT. PAL Indonesia (Persero) telah memiliki peraturan atau kebijakan di perusahaannya terkait KTR, seperti dilarang keras merokok pada saat bekerja, dilarang membuang puntung rokok sembarangan, dan sanksi yang akan dikenakan bagi pelanggar. Adapun sanksi yang dikenakan adalah penundaan pembayaran gaji/ natura/pemotongan gaji atau denda. PT. PAL Indonesia (Persero) juga memiliki peraturan yang belum tertulis namun sudah disosialisasikan, yakni dilarang merokok ketika berjalan di seluruh area PT. PAL Indonesia (Persero). Pengawasan yang dilakukan di PT. PAL Indonesia (Persero) terkait KTR telah dijalankan oleh tim HSE (Health, Safety, Environment). 
J urnal Promkes: The Indonesian J ournal of Health Promotion and Health Education Vol. 7 No. 1 (2019) 12-21. doi: 10.20473/ jpk.V7.I1.2019.12-21

Tabel 2. Pengkategorian Hasil Pervariabel

\begin{tabular}{lcccccc}
\hline \multirow{2}{*}{ Variabel } & \multicolumn{2}{c}{ Tinggi } & \multicolumn{2}{c}{ Sedang } & \multicolumn{2}{c}{ Rendah } \\
\cline { 2 - 7 } & $\mathbf{N}$ & $\%$ & $\mathbf{N}$ & $\%$ & $\mathbf{N}$ & $\%$ \\
\hline $\begin{array}{l}\text { Kedekatan } \\
\text { Pengawas }\end{array}$ & 13 & 17,33 & 54 & 72 & 8 & 10,67 \\
\hline $\begin{array}{l}\text { Tanggung } \\
\text { Jawab }\end{array}$ & 22 & 29,33 & 53 & 70,67 & 0 & 0 \\
$\begin{array}{l}\text { Pekerja } \\
\text { Dukungan }\end{array}$ & 18 & 24 & 54 & 72 & 3 & 4 \\
$\begin{array}{l}\text { Rekan } \\
\text { Kerja }\end{array}$ & 7 & 9,33 & 63 & 84 & 5 & 6,67 \\
\hline $\begin{array}{l}\text { Status } \\
\text { Pengawas }\end{array}$ & 74 & 98,67 & 1 & 1,33 & 0 & 0 \\
\hline $\begin{array}{l}\text { Kepatuhan } \\
\text { KTR }\end{array}$ & & & & & \\
\hline
\end{tabular}

\section{Kedekatan Pengawas dengan Pekerja}

Tabel 2 menunjukkan pengkategorian pada tingkat kedekatan pengawas paling banyak terdapat pada kategori sedang sejumlah 54 responden dengan persentase $72 \%$, sedangkan pada kategori tinggi sebesar 17,33\% dan kategori rendah sebesar $10,67 \%$. Pekerja terbanyak berada pada kategori sedang. Hal ini menunjukkan bahwa pekerja tidak terlalu dekat dengan pengawas.

Kedekatan antara pekerja dengan pengawas dapat ditunjukkan melalui interaksi. Menurut Shaw, interaksi merupakan suatu pertukaran antar pribadi yang masing-masing orang menunjukkan perilakunya satu sama lain dan dapat mempengaruhi perilaku satu sama lain. Interaksi yang dilakukan dapat berupa interaksi verbal, fisik, maupun emosional (Ali, 2010). Aspek yang dinilai pada kedekatan pengawas antara lain cara berkomunikasi, interaksi yang dilakukan oleh pengawas, serta pemberian penyuluhan di tempat kerja. Sebesar 72\% pekerja menilai bahwa pengawas cukup dekat dengan pekerja. Hasil tersebut menunjukkan bahwa pengawas cukup sering memberikan arahan atau peringatan pada pekerja di divisi tersebut.

\section{Tanggung Jawab Pekerja Terhadap Peraturan KTR}

Tabel 2 menunjukkan bahwa jumlah responden terbanyak terdapat pada kategori sedang sebesar 70,67\%, sedangkan pada kategori tinggi sebesar 29,33\%, dan kategori rendah sebesar $0 \%$. Jumlah pekerja terbanyak berada pada kategori sedang. Hal ini menunjukkan bahwa pekerja memiliki rasa tanggung jawab yang cukup.

Tanggung jawab adalah wajib menanggung, wajib memikul beban, wajib memenuhi segala akibat yang timbul dari perbuatan, rela mengabdi, dan rela berkorban untuk kepentingan pihak lain (Muhammad, 2000). Penilaian tanggung jawab pekerja pada penelitian ini antara lain kebiasaan merokok di tempat kerja, penggunaan area khusus merokok, risiko melanggar KTR, dan respons pekerja terhadap kesesuaian penetapan KTR di PT. PAL Indonesia (Persero). Sebesar 70,67\% pekerja memiliki tanggung jawab yang sedang. Hal ini menunjukkan bahwa pekerja cukup bertanggung jawab pada penerapan KTR di perusahaannya.

\section{Dukungan Rekan Kerja Terhadap Peraturan KTR}

Tabel 2 menunjukkan pengkategorian pada tingkat dukungan rekan kerja paling banyak terdapat pada kategori sedang yakni sebesar $72 \%$, sedangkan pada kategori tinggi sebesar 24\%, dan kategori rendah sebesar 4\%. Hal ini menunjukkan bahwa sebagian besar pekerja saling mendukung satu sama lain.

Seseorang yang berada pada lingkungan yang memiliki kesamaan dengan dirinya baik umur, jenis kelamin, agama, pekerjaan, maupun hobi, cenderung akan berperilaku sesuai dengan keadaan lingkungannya. Bagi mereka yang tidak sejalan dengan lingkungan tersebut, maka cenderung dihindari oleh lingkungan sosialnya. Jika dalam kelompok tersebut terdapat perilaku patuh, maka seluruh anggota kelompok cenderung akan patuh. Penilaian untuk dukungan rekan kerja meliputi implementasi KTR, kesediaan untuk menegur dan memberi saran, serta pengawasan. Sebesar $72 \%$ pekerja menilai bahwa rekan kerjanya cukup mendukung pelaksanaan peraturan terkait KTR di PT. PAL Indonesia (Persero).

\section{Status Pengawas dalam Perusahaan}

Tabel 2. menunjukkan pengategorian status pengawas paling banyak terdapat pada kategori sedang sebesar $84 \%$, sedangkan pada kategori tinggi sebesar $9,33 \%$, dan kategori rendah sebesar $5 \%$. 
Seseorang dapat disebut sebagai pengawas apabila telah memenuhi kualifikasi yang telah ditetapkan perusahaan. Kedudukan seorang figur otoritas sesuai dengan penguasaan pengetahuan dalam bidang tertentu (Wirawan, 2003). Pengawas terkait KTR harus menguasai bidang kesehatan dan keselamatan kerja.

Simbol status adalah penggunaan simbol atau lambang untuk menunjukkan kedudukan seseorang dalam masyarakat yang diwujudkan dalam bentuk tingkah laku sesuai dengan status yang dimilikinya (Ulum, 2015). Pada PT. PAL Indonesia (Persero), simbol status sebagai pengawas adalah dengan menggunakan jaket merah yang bertuliskan HSE. Pekerja dapat dengan mudah mengenali pengawas dengan melihat seragam atau jaket yang dikenakan. Pada kebijakan di PT. PAL Indonesia (Persero), diatur bahwa pekerja subkon dilarang menggunakan wearpack dengan warna merah. Hal ini dilakukan untuk mengantisipasi kesalahan atau penyalahgunaan wewenang yang dilakukan oleh pekerja.

Aspek yang dinilai pada status pengawas antara lain, pendidikan terakhir, kesesuaian dengan kualifikasi sebagai pengawas, kedisiplinan dalam menjalankan tugas dan kedudukan. Sebesar 84\% pekerja memiliki tingkat kepercayaan pada status pengawas yang sedang. Hal ini menunjukkan bahwa pekerja menganggap pengawas cukup sesuai dengan kualifikasi yang telah ditetapkan oleh perusahaan.

\section{Kepatuhan Kawasan Tanpa Rokok (KTR)}

Tabel 2 menunjukkan hasil responden dengan tingkat kepatuhan tinggi sebesar $98,67 \%$, sedangkan pada kategori sedang hanya 1 responden atau 1,33\%. Hal ini menunjukkan bahwa pekerja di salah satu divisi di PT. PAL Indonesia (Persero) telah memiliki kepatuhan yang baik terkait KTR.

Kepatuhan adalah tingkat seseorang dalam melakukan suatu aturan dan perilaku yang disarankan (Smet, 1994). Menurut Milgram, kepatuhan terkait dengan ketaatan seseorang pada otoritas aturan-aturan. Hasil penelitian yang telah dilakukan di PT. PAL Indonesia (Persero) menunjukkan sebesar 98,67\% pekerja memiliki kepatuhan yang tinggi. Kepatuhan yang tinggi diharapkan dapat meminimalisir pelanggaran terkait KTR karena setiap pekerja menyadari dan menerima peraturan terkait KTR yang telah diterapkan di tempat kerjanya.

\section{Hubungan Kedekatan Pengawas dengan Kepatuhan KTR}

Tabel 3 menunjukkan hasil yang didapatkan dari uji Korelasi Spearman antara kedekatan pengawas dengan kepatuhan KTR yakni memiliki nilai signifikan 0,702 ( $p>0,05)$. Hal tersebut menunjukkan bahwa tidak terdapat hubungan antara kedekatan pengawas dengan kepatuhan KTR. Correlation coefficient $(r)-0,45$, menunjukkan bahwa terdapat korelasi sebesar 20,25\%. Tanda negatif pada korelasi tersebut mengandung arti bahwa hubungan tersebut berbanding terbalik, dengan kata lain semakin tinggi kedekatan pengawas maka semakin rendah kepatuhan KTR di perusahaan tersebut.

Berbeda dengan hasil penelitian yang menyatakan bahwa terdapat hubungan antara kedekatan figur otoritas dengan kepatuhan penulisan resep obat sesuai formula. Hal tersebut dapat dilihat dari meningkatnya jumlah kepatuhan ketika kedekatan dalam kondisi baik (Mahfudhoh, 2015). Eksperimen yang dilakukan oleh Milgram juga menyebutkan bahwa kedekatan figur otoritas dapat mempengaruhi tingkat kepatuhan seseorang. Seorang figur otoritas yang meninggalkan ruangan dan menyampaikan instruksinya melalui telepon, kepatuhan cenderung menurun (Atkinson, 1983). Jika figur otoritas memberikan instruksinya

Tabel 3. Uji Korelasi Spearman Antara Kedekatan Pengawas dengan Kepatuhan KTR

\begin{tabular}{llll}
\hline \multicolumn{4}{c}{ Correlations } \\
\hline & & $\begin{array}{c}\text { Kepatuhan } \\
\text { KTR }\end{array}$ & $\begin{array}{l}\text { Kedekatan } \\
\text { Pengawas }\end{array}$ \\
\hline Kedekatan & $\mathrm{r}$ &,- 045 & 1,000 \\
Pengawas & Sig. &, 702 & $\cdot$ \\
& $\mathrm{N}$ & 75 & 75 \\
\hline Kepatuhan & $\mathrm{r}$ & 1,000 &,- 045 \\
KTR & Sig. & $\cdot$ &, 702 \\
& $\mathrm{~N}$ & 75 & 75 \\
\hline
\end{tabular}


secara langsung, maka kepatuhan akan cenderung lebih tinggi.

Hasil penelitian yang tidak berhubungan tersebut dapat disebabkan oleh beberapa faktor. Hasil analisis yang menunjukkan hubungan yang berbanding terbalik, memberi simpulan bahwa pekerja yang memiliki kedekatan yang baik dengan pengawas akan memiliki kepatuhan terhadap kebijakan KTR yang buruk. Pekerja yang memiliki kedekatan yang baik dengan pengawas akan cenderung mengabaikan instruksi yang diberikan oleh pengawas tersebut. Pekerja menganggap pengawas sebagai teman dekat yang akan memaklumi apabila ia melakukan pelanggaran KTR.

Penyebab lainnya yakni luasnya lokasi dan banyaknya jumlah pekerja di divisi tersebut. Lokasi yang cukup luas serta jarak yang cukup jauh antara satu bengkel ke bengkel lain dapat menjadi penyebab kurangnya pekerja merasakan kedekatan dengan pengawas, apalagi jumlah pekerja di divisi tersebut tidak sebanding dengan jumlah pengawas. Hal ini membuat pengawas memiliki keterbatasan untuk menjangkau seluruh pekerja dalam waktu yang singkat.

\section{Hubungan Tanggung Jawab Pekerja dengan Kepatuhan KTR}

Tabel 4 menunjukkan hasil dari uji Korelasi Spearman antara tanggung jawab pekerja dengan kepatuhan KTR dengan nilai signifikan 0,031 $(p<0,05)$. Hal ini berarti ditemukan adanya hubungan antara tanggung jawab pekerja dengan kepatuhan KTR. Correlation coefficient ( $r$ )

Tabel 4. Uji Korelasi Spearman Antara Tanggung Jawab Pekerja dengan Kepatuhan KTR

\begin{tabular}{|c|c|c|c|}
\hline \multicolumn{4}{|c|}{ Correlations } \\
\hline & & $\begin{array}{c}\text { Kepatuhan } \\
\text { KTR }\end{array}$ & $\begin{array}{c}\text { Tanggung } \\
\text { Jawab } \\
\text { Pekerja }\end{array}$ \\
\hline \multirow{3}{*}{$\begin{array}{l}\text { Tanggung } \\
\text { Jawab } \\
\text { Pekerja }\end{array}$} & $r$ & ,249 & 1,000 \\
\hline & Sig. & 031 & . \\
\hline & $\mathrm{N}$ & 75 & 75 \\
\hline \multirow{3}{*}{$\begin{array}{l}\text { Kepatuhan } \\
\text { KTR }\end{array}$} & $r$ & 1,000 & ,249 \\
\hline & Sig. & . & ,031 \\
\hline & $\mathrm{N}$ & 75 & 75 \\
\hline
\end{tabular}

0,249, yang berarti korelasi sebesar 6,2\%. Hal ini dapat disimpulkan bahwa hubungan tersebut berbanding lurus, dengan kata lain apabila tanggung jawab pekerja tinggi maka kepatuhan KTR juga tinggi.

Sesuai dengan eksperimen Milgram, yakni orang dengan komitmen atau pribadi yang kuat akan lebih patuh dibandingkan dengan orang yang memiliki komitmen rendah (Sarwono, 1993). Penelitian lain juga menyebutkan bahwa terdapat pengaruh dari tanggung jawab terhadap kepatuhan pendokumentasian asuhan keperawatan. Sebagian perawat mengambil tanggung jawab penuh untuk melaksanakan asuhan keperawatan dengan baik meskipun sebagian tanggung jawab tersebut ada pada atasan (Ulum, 2013).

Instruksi yang diberikan oleh pengawas mungkin bisa ditaati atau justru sebaliknya. Faktor yang menyebabkan pekerja mengabaikan instruksi yang diberikan oleh pengawas dapat berasal dari internal maupun eksternal. Faktor eksternal dapat berasal dari lingkungan sosial, sarana prasarana, seperti area khusus merokok, asbak, dan tanda larangan merokok yang tidak mendukung, pengawas yang kurang jelas dalam memberikan instruksi.

Faktor internal berasal dari dalam diri pekerja. Salah satunya yakni rasa tanggung jawab yang dimiliki oleh pekerja. Tanggung jawab merupakan suatu yang harus atau wajib dilakukan dan dikerjakan. Hal ini tergambarkan pada pekerja yang tidak begitu paham ketika instruksi diberikan, namun tetap mematuhi peraturan yang ada terkait KTR. Pekerja dapat menjumpai berbagai larangan merokok di seluruh area kerja dan mengetahui sanksi yang diberikan ketika melanggar pada peraturan yang dipajang di mading kantor. Area khusus merokok juga disediakan pada tiap bengkel yang dapat digunakan oleh seluruh pekerja ketika jam istirahat. Adanya rasa tanggung jawab yang dimiliki oleh pekerja akan meningkatkan kinerja terutama dalam pelaksanaan peraturan KTR di PT. PAL Indonesia (Persero).

\section{Hubungan Dukungan Rekan Kerja dengan Kepatuhan KTR}

Tabel 5. menunjukkan hasil uji Korelasi Spearman antara dukungan rekan kerja dengan kepatuhan KTR dengan 
Tabel 5. Uji Korelasi Spearman Antara Dukungan Rekan Kerja dengan Kepatuhan KTR

\begin{tabular}{llcc}
\hline \multicolumn{3}{c}{ Correlations } \\
\hline & & $\begin{array}{c}\text { Kepatuhan } \\
\text { KTR }\end{array}$ & $\begin{array}{c}\text { Dukungan } \\
\text { Rekan } \\
\text { Kerja }\end{array}$ \\
\hline Dukungan & $\mathrm{r}$ &, 188 & 1,000 \\
Rekan Kerja & Sig. &, 196 & $\cdot$ \\
& $\mathrm{N}$ & 75 & 75 \\
\hline Kepatuhan & $\mathrm{r}$ & 1,000 &, 188 \\
KTR & Sig. & $\cdot$ &, 106 \\
& $\mathrm{~N}$ & 75 & 75 \\
\hline
\end{tabular}

nilai signifikan 0,106 (p>0,05). Hal ini berarti tidak ditemukan hubungan antara dukungan rekan kerja dengan kepatuhan KTR. Correlation coefficient ( $r$ ) 0,188 yang berarti memiliki korelasi sebesar 3,53\%. Hubungan tersebut memiliki korelasi yang lemah, sehingga tidak didapatkan hasil yang signifikan.

Hasil penelitian ini tidak sejalan dengan eksperimen Milgram yang menyatakan bahwa dukungan dari rekan kerja merupakan salah satu faktor yang dapat mempengaruhi kepatuhan. Rekan kerja dapat berfungsi sebagai titik banding, baik langsung maupun tidak langsung yang membentuk sikap maupun perilaku seseorang (Mahfudhoh, 2015), namun pada penelitian lain menyebutkan bahwa dukungan rekan tidak memiliki pengaruh terhadap kepatuhan pendokumentasian asuhan keperawatan (Ulum, 2013).

Tidak adanya hubungan antara dukungan rekan kerja dengan kepatuhan KTR dapat disebabkan oleh beberapa faktor. Salah satu faktor adalah pekerja yang memiliki perasaan sungkan jika menegur atau mengingatkan pekerja lain yang merokok sembarangan karena tidak berstatus sebagai pengawas. Kemungkinan lain yang terjadi yaitu pekerja yang telah menegur tidak dihiraukan oleh pekerja lain. Lingkungan dengan kepatuhan yang rendah akan memudahkan seseorang untuk berbuat tidak patuh agar sesuai dengan kondisi lingkungan sosialnya, meskipun kepatuhan adalah hal yang penting (Fernald, 2007). Pekerja yang berada di lingkungan sosial yang memiliki kepatuhan baik akan memiliki kepatuhan yang baik pula. Hal sebaliknya terjadi, jika lingkungan sosial pekerja memiliki kecenderungan untuk tidak patuh, maka pekerja juga akan tidak patuh pada peraturan KTR.

\section{Hubungan Status Pengawas dengan Kepatuhan KTR}

Tabel 6 menunjukkan hasil uji Korelasi Spearman antara status figur otoritas dengan kepatuhan KTR dengan nilai signifikan 0,303 $(p>0,05)$. Hal tersebut menunjukkan bahwa tidak ditemukan adanya hubungan antara status figur otoritas dengan kepatuhan KTR.

Tabel 6. Uji Korelasi Spearman Antara Status Pengawas dengan Kepatuhan KTR

\begin{tabular}{llcc}
\hline \multicolumn{3}{c}{ Correlations } \\
\hline & & $\begin{array}{c}\text { Kepatuhan } \\
\text { KTR }\end{array}$ & $\begin{array}{c}\text { Status } \\
\text { Pengawas }\end{array}$ \\
\hline Status & $\mathrm{r}$ &,- 121 & 1,000 \\
Pengawas & Sig. &, 303 & $\cdot$ \\
& $\mathrm{N}$ & 75 & 75 \\
\hline Kepatuhan & $\mathrm{r}$ & 1,000 &,- 121 \\
KTR & Sig. & $\cdot$ &, 303 \\
& $\mathrm{~N}$ & 75 & 75 \\
\hline
\end{tabular}

Correlation coefficient $(r)-0,121$, berarti memiliki korelasi sebesar $1,46 \%$. Korelasi tersebut menunjukkan bahwa terdapat hubungan yang berbanding terbalik, dengan kata lain semakin tinggi tingkat kepercayaan pada status figur otoritas, maka semakin rendah kepatuhan KTR.

Hasil penelitian ini sejalan dengan penelitian lain yang menyatakan bahwa status figur otoritas tidak berhubungan dengan kepatuhan penulisan resep sesuai formularium (Mahfudhoh, 2015), namun berdasarkan eksperimen yang dilakukan oleh Milgram, status figur otoritas memiliki pengaruh terhadap kepatuhan. Penggunaan jas laboratorium membuat seseorang memiliki peran penting, memiliki wewenang, dan terlihat profesional. Saat pemberi perintah adalah orang yang tidak menggunakan jas laboratorium, kepatuhan menurun menjadi 20\% (Sarwono, 1993).

Tidak adanya hubungan antara status figur otoritas dengan kepatuhan KTR di PT. PAL Indonesia (Persero) dapat disebabkan oleh beberapa faktor, antara lain faktor status pendidikan terakhir 
J urnal Promkes: The Indonesian J ournal of Health Promotion and Health Education Vol. 7 No. 1 (2019) 12-21. doi: 10.20473/ jpk.V7.I1.2019.12-21

pengawas yang sama dengan beberapa pekerja lain, serta adanya beberapa item kualifikasi untuk menjadi pengawas yang juga sama dengan kualifikasi pekerja di bidang tertentu. Hal tersebut menyebabkan pekerja merasa memiliki posisi yang setara dengan pengawas, sehingga pekerja akan mengabaikan instruksi dari pengawas. Hal ini membu sehingga tidak terjadi kepatuhan KTR yang diharapkan.

\section{SIMPULAN}

Pekerja yang berada di salah satu divisi di PT. PAL Indonesia (Persero) telah memiliki kepatuhan KTR yang baik. Hal ini dapat dibuktikan dengan tingkat kepatuhan KTR yang tinggi. Hasil penelitian yang dilakukan menyimpulkan bahwa faktor yang memiliki hubungan dengan kepatuhan KTR di PT. PAL Indonesia (Persero) adalah tanggung jawab personal.

\section{DAFTAR PUSTAKA}

Ali, M. 2010. Psikologi Remaja (Perkembangan Peserta Didik). Jakarta: PT. Bumi Aksara.

Ali, U. 2015. Pengertian, Tujuan dan Proses Kebijakan Publik. Dilihat pada 1 November 2017. http://www. pengertianpakar. com/2015/10/pengertian-tujuan-danproses-kebijakan-publik.html.

Anderson, JE. 1979. Public Policy Making. Boston: Houghton Mifflin.

Anonim. 2017. Rokok Ancam Pembangunan Indonesia. Metro TV News. Dilihat pada 8 November 2017. http://ekonomi. metrotvnews.com/mikro/Dkq67XZKrokok-ancam-pembangunan-indonesia.

Atkinson. 1983. Pengantar Psikologi. Jakarta: Erlangga.

Deny. 2017. Analisis Risiko Kebakaran di Rumah Sakit Islam Surabaya. Surabaya: Universitas Airlangga. Skripsi.

Dunn, WN. 2003. Analisis Kebijakan Publik. Yogyakarta: Gadjah Mada University Press.

Fernald, D. 2007. Psychology. Dilihat pada 10 Oktober 2017. http: / /www.prenhall. com/fernald/chapter/fem4.html.

Instruksi Menteri Kesehatan Republik Indonesia Nomor 84/MENKES/INS/ II/2002 Tentang Kawasan Tanpa Rokok di Tempat Kerja dan Sarana Kesehatan.
Mahfudhoh, S, Rohmah TN. 2015. Faktor yang Mempengaruhi Kepatuhan Penulisan Resep Sesuai Formularium. Jurnal Administrasi Kesehatan Indonesia, 3 (1), 21 - 30.

McLeod, SA. 2007. Milgram Experiment. Dilihat pada 20 Januari 2018. http:// www.simplypsychology.org/milgram. html.

Milgram, S. 1963. Behavioral Study of Obedience. Journal of Abnormal and Social Psychology, 67, 371 - 378.

Muhammad, A. 2000. Hukum Perdata Indonesia. Bandung: PT. Citra Aditya Bakti.

Myers, DG. 2014. Psikologi Sosial. Jakarta: Salemba Humanika.

Notoatmodjo, S. 2003. Pendidikan dan Perilaku Kesehatan. Jakarta: Rineka Cipta.

Peraturan Pemerintah Republik Indonesia Nomor 19 Tahun 2003 Tentang Pengamanan Rokok Bagi Kesehatan.

Peraturan Pemerintah Republik Indonesia Nomor 109 Tahun 2012 Tentang Pengamanan Bahan yang Mengandung Zat Adiktif Berupa Produk Tembakau Bagi Kesehatan.

Permana, N. 2015. Blog Kebakaran. Diakses pada 5 Januari 2018. http://patigeni. com/kebakaran-di-tempat-kerja/.

Rahajeng, Ekowati. 2015. Pengaruh Penerapan Kawasan Tanpa Rokok Terhadap Penurunan Proporsi Perokok di Provinsi DKI Jakarta, Daerah Istimewa Yogyakarta dan Bali. Jurnal Ekologi Kesehatan, 14 (3), 238 - 249.

Sarwono. 1993. Psikologi Sosial Suatu Pengantar. Yogyakarta: Fakultas Psikologi Universitas Gadjah Mada.

Shaw, ME. 1979. The Psychology of Small Group Behavior. New Delhi: The McGrawHill Publishing Company Ltd.

Smet, Bart. 1994. Psikologi Kesehatan. Jakarta: PT. Gramedia Widiasarna Indonesia.

Subarsono, AG. 2015. Analisis Kebijakan Publik. Yogyakarta: Pustaka Pelajar.

Sugiyono. 2008. Metode Penelitian Bisnis. Bandung: Pusat Bahasa Depdiknas.

Supranto, J. 2007. Teknik Sampling Untuk Survei dan Eksperimen. Jakarta: Rineka Cipta.

Ulum, Miftachul. 2013. Faktor yang Mempengaruhi Kepatuhan 
Pendokumentasian Asuhan Keperawatan Berdasarkan Teori Kepatuhan Milgram. Jurnal AKK, 1 (3), 252 - 262.

Undang - Undang Republik Indonesia No. 1 Tahun 1970 Tentang Keselamatan Kerja.

Winarno, B. 2007. Kebijakan Publik: Teori dan Proses. Yogyakarta: Media Pressindo.
Wirawan. 2003. Kapita Selekta Teori Kepemimpinan: Pengantar untuk Praktek dan Penelitian Jilid 1. Jakarta.

Yusuf, FJ. 2014. Penerapan Perda No. 5 Tahun 2008 Tentang Kawasan Tanpa Rokok dan Kawasan Terbatas Merokok di RSUD dr. Mohamad Soewandhie Surabaya. Surabaya: Universitas Airlangga. Skripsi. 